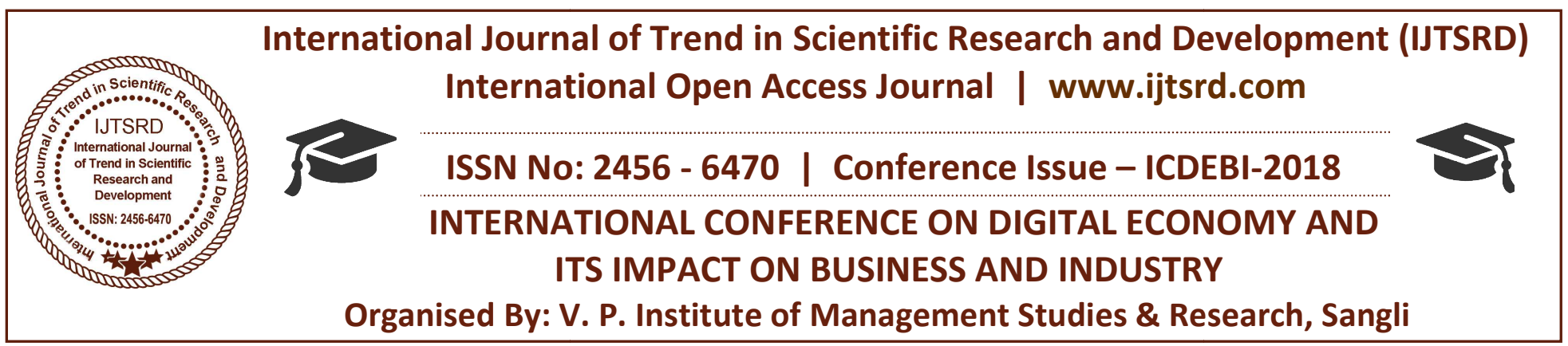

\title{
Digitalization in Banking Sector
}

\author{
Arati B. Pawadi \\ KLE Society's Basavprabhu Kore Arts, Science and Commerce College, \\ Chikodi, Karnataka, India
}

\begin{abstract}
Digital transformation is far beyond just moving from traditional banking to a digital world. It is and other financial institutions learn about, interact with and satisfy customers. An efficacious digital transformation begins with an understanding of digital customer behavior, preferences, choices, and likes, dislikes, stated as well as unstated needs aspirations etc... And this transformation leads to the major changes in the organization, from product centric to customer centric view.
\end{abstract}

The most effective way to understand and bring the organization from traditional banking to digital banking is omni channel approach. As customers continue to change their channel usage patterns, bank and credit firms need to focus on delivering a seamless customer experience across touch points. More than just an axiom, omni channels banking is a prospect to take bottom line on higher note by gaining insights from customer channels, behavior and preferences. Today's customers are more sophisticated and tech savvy, and to cater to their specific needs, each customer need unique customers from banking. They want the companies to understand their unstated needs as well as their likes. So, it should come as no surprise that these customers are expecting similar kind of response and service from banking institution too. From researching new service, opening an account, checking balance, conducting transactions, loans, credits, wealth management, customer support, and experience has become a key to success in this competitive market place.

\section{INTRODUCTION}

Banking industry is going through of commoditization .In today's scenario, differentiated and delightful customer experience has become more important than just providing financial service. To grab a bigger price of the cake, banking industry has to understand the unstated needs of the customer the way airlines understands the preference of the frequent players or the retailers understand the likes/dislikes of their customers, without even taking direct feedback of the customers.

Each and every day, new device /technologies are providing various customers touch points. Every time customers touch a computer or a screen, they are providing an information trail and its banks responsibility to understand how they use this trail to move their bottom line upwards. Traditionally bank spent most of their efforts, time and money on transaction execution, which is nothing but has become a very basic feature of their overall service. While providing expedient, consistent and precise transaction processing abilities still critical, we believe that banks can learn from how retailers see the customers' journey through an Omni channel lens. Banks now need to rethink the way customers are being valued, may be from the angle of the industries that greatly value customer experience.

\section{CURRENT PROCESS}

Initially, customer logins to its bank website and looks at the current assets and liabilities, based on various analytics algorithms bank suggest money investment options as well as borrowing options as per the eligibility .Customers portal also gives a brief picture of current financial markets and its impact to the customers current financial position, in case customers wants go ahead with any of the investment suggested or borrowing options , and he/ she can have 
at the brochure and get in touch with the customer representative for taking the process ahead. This process involves a lot of manual intervention in terms of converting suggestions/decisions into real investment which also takes a lot of time.

The users does a basic search on the internet for buying any financial products and the post that, raises a query of request with the bank for further information. User raises the query, either through website or calling of the customer care .Based on the query and field of the query, customer representatives forwards the call to the specific department and arranges a meeting with the use .The user ,then ,selects either video conference with expert or the physical meeting .Before the meeting multiple fields query ,the users decides whether to have all physical meetings or video conferencing .Post reviewing all the suggestions user accept or reject the suggestions if any of the suggestion is accepted then the representative goes ahead with the paper work or other formalities.

\section{Limitations of current process}

$>$ Personal assistance from the banks perspective is must.

$>$ Separate meetings for the various products.

$>$ Users need track all products separately.

$>$ Bank suggestion based on only users financial strengths.

$>$ Service based on user's stated needs.

\section{Role of digitalization in banking}

Banks are not just a part of our lives, but have a significant role in our daily lives. For many, day will not be end without at least a single financial transaction. Thus banks always try to adopt latest technologies to enhance customer experience.

Digitalization is not an option for banking industry, rather it is inevitable because every industry is being digitalized and banking sector is no exception.

Mobile banking is increasing at a fast pace more than online banking.

\section{Advantages of digitalization in banking}

$>$ Improved customer experience.

$>$ Reduction of cost for banks and customers as well by using ATMs, cashless transaction etc.

$>$ With more digital data available with banks, they can take data driven dynamic decisions by using digital analytics. This benefits both customers and banks.

$>$ Technology is non -discriminatory. Everyone will be treated same at banks.

$>$ Number of customers will be increased for banks because of the increased convenience of banking.

$>$ Digitalization reduces human error.

$>$ Need of handling large amounts of cash will be reduced?

$>$ Opening and maintaining bank accounts are never been easier.

$>$ Repetitive task will be eliminated by automation.

$>$ Rural and urban gap will be eliminated.

$>$ With the increasing cashless transaction, fake currency threat will be reduced.

Productivity will be increased.

Disadvantages of digitalization in banking

$>$ Digitalization reduce the effort of employees and hence results in loss of jobs.

Some bank branches may cease to exist with the increasing use of online banking.

Banks will be more vulnerable to cyber attacks.

Privacy may have to be compromised.

Major technology trends that will reshape banking are as follow

1. Open banking is the new norm.

Open banking a connected ecosystem for financial and non financial services with multiple underlying services providers is the future of banking. The launch of UPI by the National Payments Corporation of India (NPCI)has thrown open the gates for innovation in the open banking space.

2. Banking on the could first strategy

Progressive banks are already making strides in cloud adoption .Disruptive technologies that are changing the face of business .Business models for emerging banks also be largely driven by the cloud first strategy. Demonetization is pushing India towards a cashless society, and as banks prepare to deal with the increased influx of electronic transactions, cloud will provide with the required elasticity to meet these demands.

3. Usage of Blockchalns

As banks try to become more efficient to meet the increasing demands of customers, blockchalns will be one of the enable for reimaging process. In 2017, banks will increasingly move some projects from pilot to production and leverage blockchaln to automate inter organizational processes. 
4. More things to bank on

The year 2016 was the year of mobile first strategy. Indian banks leveraged the increasing adoption of mobile to provide customized offerings on their apps. However, digital technologies are evolving at an unprecedented rate, and so is customer adoption.

5. All of these overlying technologies will be built on the bedrock of banking architectural simplification. The new year will see banks move to componentization instead of the traditional monolithic architecture.

6. Cyber security Increasing cyber attacks and online frauds gives sleepless night to several CEOs. The end result is going to be much more increasing in information security appending.

The world has changed and continues to change rapidly. The convergence of telecom, media and computing has charged the way we work, play and live. Everything is moving faster -trends, news, products, markets, etc.

\section{Conclusion}

With the increasing usage of smart phones, digitalization of banking sector is inevitable to catch up the increasing expectations of the world. It indeed reduces human errors and increased convenience. But the fact that cyber threats are on the rise, banks must be very careful and should be prepared to handle cyber attacks.
The major ongoing development that $\mathrm{i}$ have described in my remarks today represents a speed and scale of change that goes above and beyond what I would call normal. We should be aware of the risk that such high pace of change generates and seek to seek to stay on top of those risks.

It also a good time for consumers as a technology pushes us towards the possibility of having smoother service provision. Straight through digitalized process potentially allow us to quickly access and purchase the service we want without the need for manual inputs that can slow things down

Let us therefore embrace technological change where it helps us to achieve those stable long term objective. I believe we are already making on all sides significant progress in this work. If we continue with the right attitude, we have an exacting time ahead and together we can help generate the a better banking system for customers and citizens in to the future.

\section{REFERENCE:}

1. Article, pdf, wiki pied, Magazines, Teachers, Commerce Books. 